\title{
Anti-Inflation Process Continues
}

\author{
by NORMAN N. BOWSHER
}

T

HE RATE OF INFLATION has accelerated since 1965 , until in the past year overall prices have risen more than 5 per cent. Progress in reducing inHation has been very slow, both because the inflation was permitted to develop momentum from 1964 through 1968, and because a gradual approach has been applied in correcting it in 1969 and 1970.

Growth in total spending has been slowed to about the estimated growth in productive capacity since the third quarter of 1969 . Production and employment have been affected adversely, but the adjustment has been much less than in previous periods of economic correction. Construction has been cut back, and bond and stock prices have fallen. ${ }^{1}$

This article reviews the recent growth trend of the money stock. To evaluate this trend and possible future trends, the article examines some evidence bearing on the current growth rate in the amount of money demanded. It also examines some credit and regulatory developments that might affect the Federal Reserve System's control of the money stock in the near future.

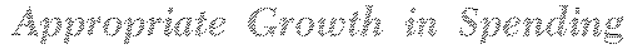

Two crucial questions for current stabilization policy are: (1) What rate of growth of total spending is most desirable to keep downward pressure on inflation and expectations of inflation? (2) What rate of monetary expansion is consistent with such a growth of total spending?

Studies conducted by this bank indicate that a moderate 6 to 7 per cent rate of growth of total spending would gradually reduce the rate of increase in overall prices from 5.3 per cent a year in the first half of 1970 to about 3,5 per cent a year in the first

${ }^{1}$ An article in this Review last month ("Inflation and Its Cure," pp. 2-7) concluded that many of these costs probably resulted from the public adapting to the higher rates of anticipated inflation, and the downward pressure on prices remained light.

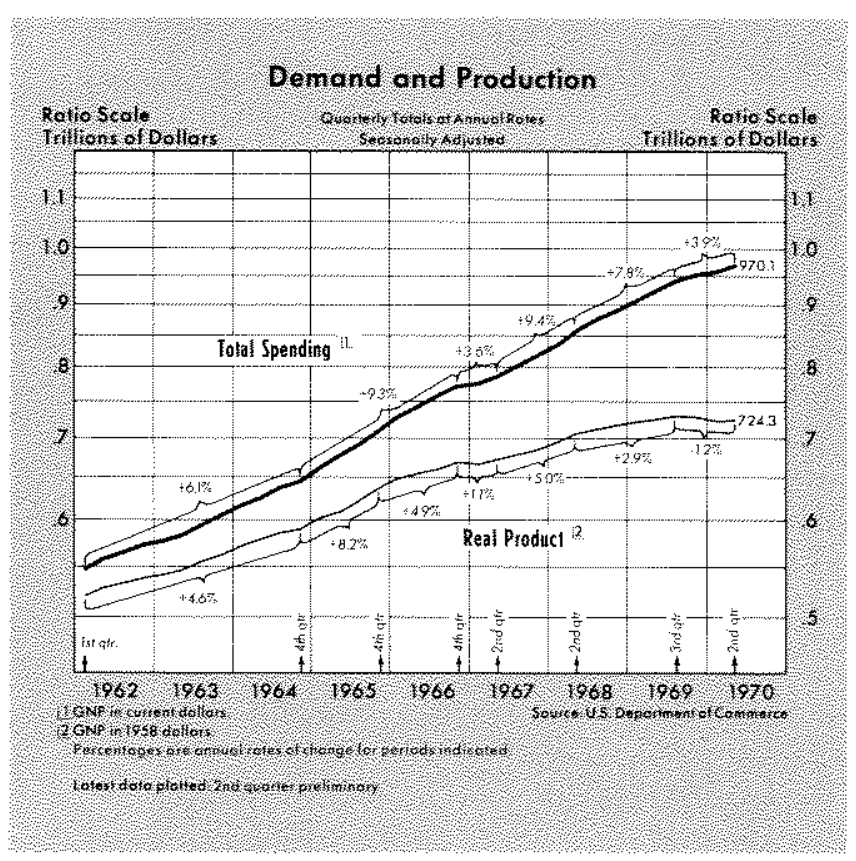

half of 1972.2 According to these estimations, total real output would rise about 1 per cent in the next twelve months and nearly 4 per cent in the following year.

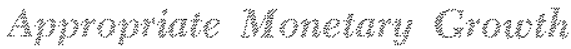

Total spending for goods and services may accelerate or decelerate as a result of any one of a number of disturbances. One such disturbance is a change in the money stock initiated by the monetary authorities relative to the amount of money demanded by the public. Important factors affecting amount of money demanded are spending, income, wealth, prices of goods and services, and interest rates. The amount of money demanded is little affected in the short rum by those factors which determine the supply.

2Calculated using the model discussed in "A Monetarist Model for Economic Stabilization," Leonall C. Andersen and Keith M. Carlson, April 1970 issue of this Review, pp. 7-25. For current simulations, see the "Quarterly Economic Trends" release of this Bank. 
If the money stock is greater (or less) than the equilibrium amount demanded at prevailing economic conditions, the resulting discrepancy tends to cause the rate of spending on goods, services, and financial assets to increase (or decrease). The process will continue until, with new levels of spending, income, prices, wealth, and interest rates, the amount of money demanded equals the amount supplied.

The equilibrium amount of money demanded at a point in time can only be measured indirectly. Some evidence can be obtained on whether it is greater or smaller than the amount supplied by observing whether the general trend of spending is accelerating or decelerating. When the rate of growth of spending remains unchanged for a prolonged period, the amount of money demanded is evidently rising at about the same rate as the money stock.

Some insight into the rate of monetary growth which would be most conducive to a moderate growth of total spending may be obtained from past experience. From the 1957 high in business activity to the high in 1965, when the money stock grew at an average 2.2 per cent a year, the trend growth in total spending was 5.7 per cent a year.

Since economic conditions were similar in 1957 and 1965 , the amount of money demanded also rose at roughly a 2.2 per cent trend rate from 1957 to 1965. However, the amount of money demanded is probably rising at a faster rate now, requiring a more rapid injection of money to avoid having a depressing effect on total spending. Prices are now rising more rapidly than from 1957 to 1965 and are expected to continue to rise for some time, requiring more money for transactions. Interest rates generally rose in the earlier period, increasing the alternative cost of holding nonearning cash balances. If interest rates now stabilize or decline, as seems likely, this incentive to reduce cash holdings will no longer exist. Also, many may feel that their overall liquidity has been reduced beyond desired levels, especially in view of recent declines in security prices, insolvency of some corporations, and talk of a money squeeze. To the extent that attempts are made to conserve and build up cash balances, growth in spending slows unless offset by a more rapid growth in money stock.

Relationships between estimated growth rates of money stock and total spending, formulated using this Bank's model, suggest that the amount of money demanded now may be rising about 6 per cent a year. To reduce inflation and inflationary expecta- tions, however, it is necessary for the stock of money to grow less rapidly than the amount demanded in order to restrain growth in total spending. Calculations at this Bank indicate that a fairly steady 5 per cent growth rate of money would be most likely to succeed in the current situation in fostering a moderate 6 per cent rate of growth in total spending in the next twelve months.

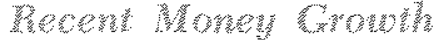

During the spring of 1970 there was a sizable injection of money, and from the first to the second quarter, the money stock rose at a rapid 6 per cent annual rate. Moreover, it is likely that in the remainder of the year the Treasury will be a large net borrower of funds, both to meet seasonal needs and to finance an expected deficit resulting from a reduced rate of tax collections as growth of incomes slows. When the Treasury borrows heavily, growth in money stock frequently is expanded rapidly by the Federal Reserve to accomodate market demands and ameliorate the higher interest rates that might otherwise result temporarily if funds have to be diverted from other uses.

Since early May, however, growth in money has been moderated. The slowing has occurred despite some money market developments which might have caused the System to continue to expand money rapidly. In late April, terms of a Treasury security

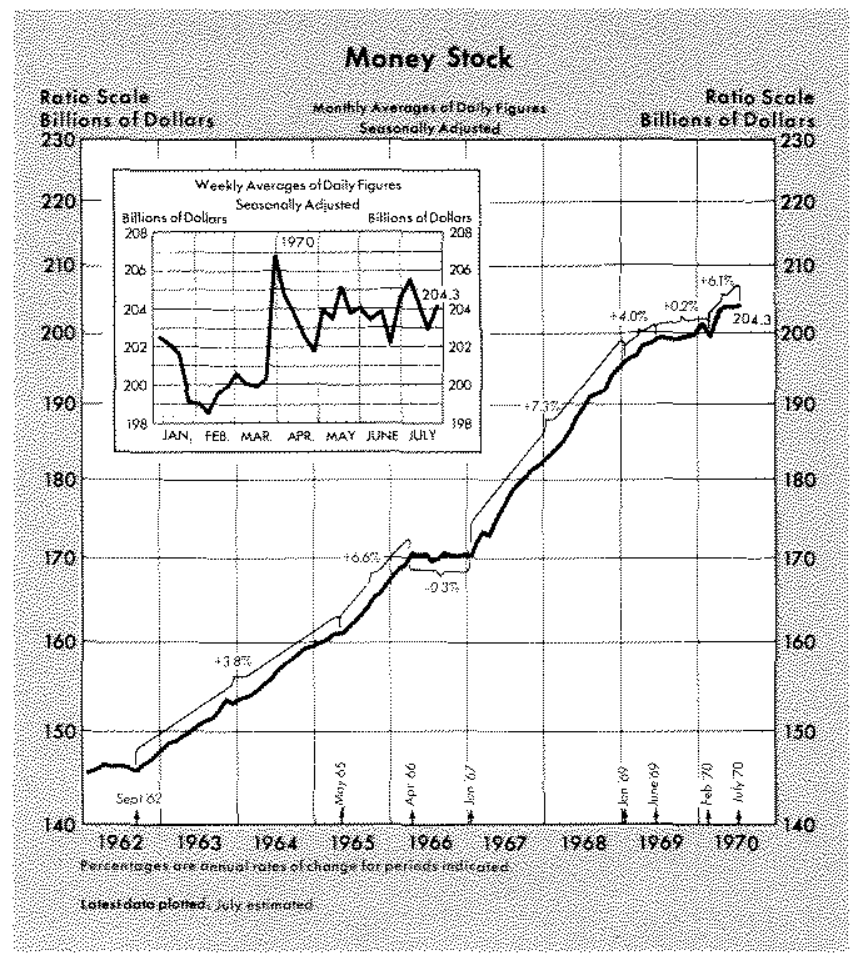


offering became unattractive in light of the sudden Cambodian invasion. To obtain sufficient buyers, the Federal Reserve expanded the money stock by injecting member bank reserves. The money and capital markets became unsettled as a result of a marked decline in stock and bond prices, the uncertain financial condition of some security dealers, the social unrest accompanying the Cambodian affair, talk of liquidity squeeze, and the insolvency of some firms, particularly the large Penn-Central Transportation Company. In addition, the Treasury borrowed about $\$ 7$ billion of new funds in July and August.

Despite the slower growth in money and unsettled money market conditions, interest rates generally declined after early May. Three-month Treasury bill

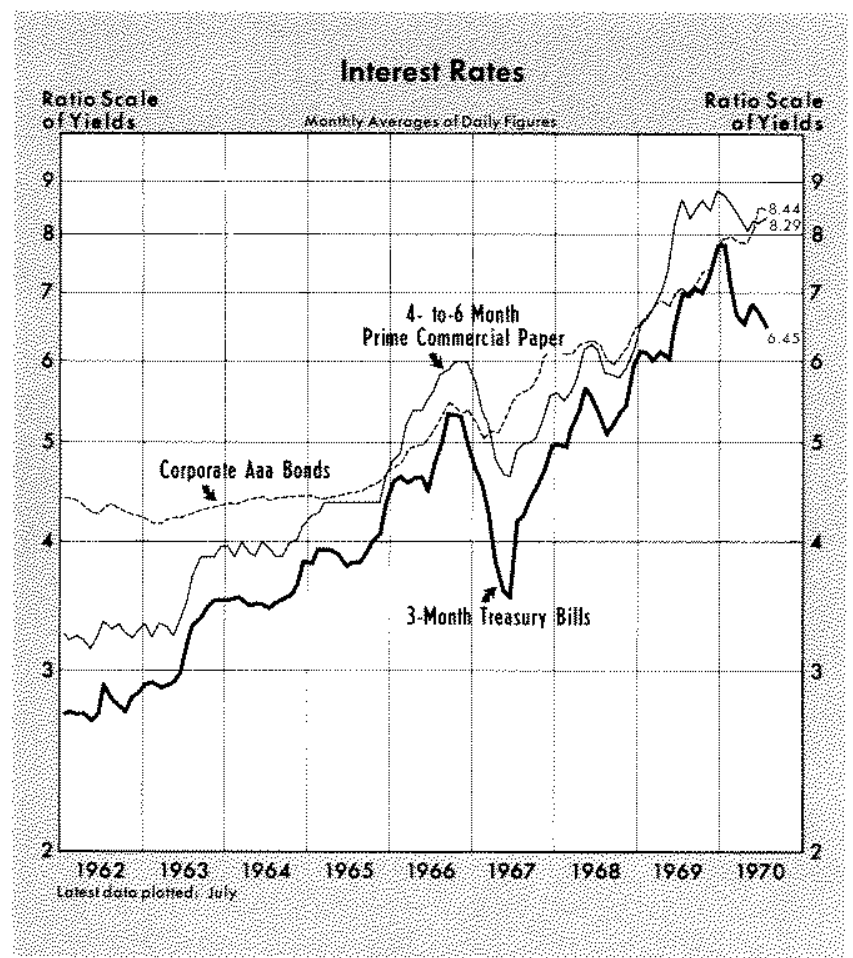

rates, which reached 8 per cent early this year and averaged 6.83 per cent in May, continued to decline and averaged about 6.50 per cent in early August. Rates on Federal funds declined from an 8.5 to 9 per cent range in the June 1969 to February 1970 period to an average 8 per cent from March to early June, and to about 7 per cent during early August.

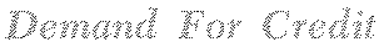

How was it possible for short-term interest rates to decline in view of a slower growth in money after early May? The demand for bank credit in the private sector moderated. Since the period is still short, the relaxation may prove to be merely a respite. But recent economic developments are similar to those during other postwar periods when we witnessed a general decline of demands for credit and of interest rates. With demands for credit less vigorous, interest rates drifted lower. Limiting growth of money, in turn, becomes easier when money market conditions are not strained.

A brief review of selected key developments indicates how credit demands may be relaxing. During 1967 and 1968 the money stock, increasing at a 7 per cent annual rate, grew more rapicly than the amount demanded by the public. As a result, total spending on goods and services and credit demands were continuously and excessively stimulated. Subsequently, the more moderate 3 per cent average rate of expansion in money since early 1969 has probably been less than growth in the amount demanded, which had been accelerating with the higher actual and expected prices.

For a time after the growth of money moderated, the stock of money held probably continued to exceed the overall amount demanded, and spending continued to be stimulated. Some individuals and businesses began to feel that their money balances were relatively low as early as the summer of 1969 and began taking actions to conserve cash, but most of the public probably continued to consider their cash balances adequate. If their balances were less than desired, the difference was small, as evidenced by the mildness of the correction in spending growth in late 1969.

With the amount of money demanded continuing to rise faster than the quantity supplied (except possibly for a brief period this spring), a growing portion of the public began taking actions to conserve and build cash balances. Individuals and businesses may undertake to improve their cash positions in many ways. Although there is reluctance to change consumption patterns or business plans, some less essential projects are trimmed or postponed in an effort to bolster cash balances, as evidenced by the moderated growth in total spending. Some individuals may have bought fewer stocks and bonds, or even liquidated some securities, in an attempt to correct a cash shortage. Although these efforts build cash holdings for some economic units, others find their cash balances declining since the total stock of money is little affected by these adjustments. At the same time, the resulting slower business conditions, and sharp declines in security prices, as well as the talk of a 
money squeeze and the widespread publicity regarding financial problems of particular firms, may have caused some to revise upward the amount of money they desired to hold.

When the growth rates of the money stock were permitted to vary much more than in recent decades, so-called money panics occurred. The amount of money demanded at times greatly exceeded the amount supplied, and short-term interest rates rose sharply as the public scrambled for the limited funds. In such periods, severe interruptions in economic activity occurred. For example, in the spring of 1920 , money, which had been expanding at a 17 per cent annual rate, suddenly began contracting at an 8 per cent rate. Yields on prime 4- to 6-month commercial paper jumped about 60 per cent within a few months, and industrial production dropped about one-third from early 1920 to early 1921 .

Since the early Fifties, rates of growth in the amount of money supplied have fluctuated over a much narrower range, and the stock of money has more nearly approximated the amount demanded. When amounts of money demanded exceeded the amount supplied, some financial strains occurred for a brief time, such as during the "credit crunch" in the early fall of 1966. The adjustments, however, were relatively mild. Rather than a widespread desperate bidding for funds in the market, driving up short-term interest rates, actions were taken to conserve cash balances, such as trimming or postponing expansion plans, policing inventories, reducing expenditures, and shortening and upgrading investment holdings. As a result, credit demands and interest rates, particularly those on short-term instruments, began declining during these postwar periods of financial stress.

Conditions during the spring and early summer of 1970 appear to be similar to other recent periods when, with the advantage of hindsight, it can be concluded that the amount of money demanded exceeded the amount supplied. If so, investment plans may have become less ebullient, and the demand for credit may have passed its peak of intensity.

\section{Control of Money Growesh}

If the demand for credit continues to be less intense in the future than it was last winter, interest rates may stabilize or decline somewhat further even though the rate of growth of money stock is restrained. Under such conditions it is much easier for the monetary authorities to limit growth of bank reserves and money than when interest rates are rising rapidly and market pressures are increasing. While moderation of growth of the money stock may in the short run keep interest rates somewhat higher than they otherwise would be, this is a necessary step to lower interest rates in the future.

Another recent development has contributed to keeping monetary growth moderate. In January the Regulation $Q$ interest rate ceilings on time deposits were raised slightly. Effective June 24, the ceiling rate was completely suspended on large CD's maturing in 30 to 89 days, permitting banks to offer yields competitive with other instruments. In the fifteen months before ceilings were relaxed in January, time deposits decreased at a 3 per cent annual rate. From January to June, time deposits increased at a 12 per cent rate, and weekly data since late June indicate another marked acceleration.

This reintermediation through banks of funds which had been flowing through commercial paper or other credit channels has little overall effect on total spending or total credit outstanding. However, since CD's and other time deposits must be supported by reserves, banks have fewer reserves available to support demand deposits (money). The additional reserves to support time deposits can be provided by the Federal Reserve. However, there has been less money market pressure to provide them with banks expanding their credit at a faster rate, since a given amount of reserves permits more bank loans and investments when liabilities are in the form of time deposits than in demand deposits.

\section{Condusions}

Inflation continues as a serious domestic economic issue, deriving from the excessive total spending from 1965 through 1968. Since early 1969 monetary actions have been directed toward dampening total spending and inflation, while holding the social and economic costs of adjusting to lower price expectations to tolerable levels.

Very restrictive monetary actions might eliminate inflation quickly, but at the expense of sharp cutbacks in production and employment. With very expansive monetary actions, inflation could not be eliminated it would accelerate.

According to calculations of this bank, a steady moderate growth of money would reduce inflationary pressures while holding the costs in terms of production slack to reasonable levels. With a 5 per cent annual rate of growth of money, it is estimated that 


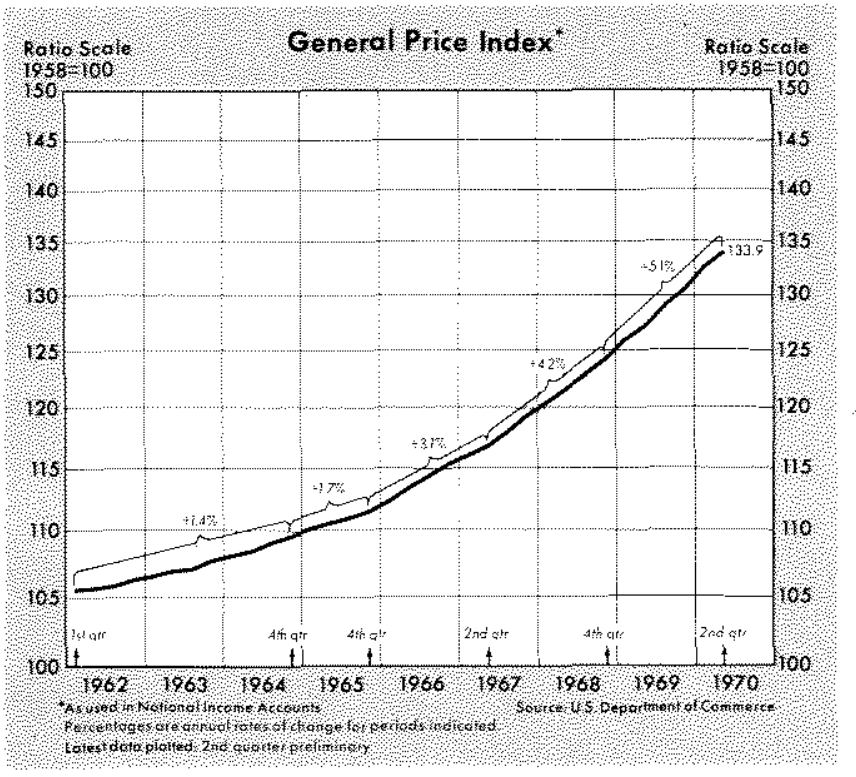

the rate of overall price increase would slow gradually from the 5.3 per cent average rate in the first half of 1970 to about a 3.5 per cent rate in the spring of 1972. Real product would expand as price rises moderate, increasing from the recent little net change to nearly 4 per cent in the twelve months ending in mid-1972.

Money has on the whole risen moderately since last December, namely, at an average 4.1 per cent annual rate, despite a rapid injection this spring. Rapid increases in the money stock may be easier to resist in the near future than from 1965 through 1968. In contrast to the earlier period, private demands for credit seem to be moderating. Also, the relaxation of Regulation $Q$ has permitted a faster growth of time deposits and bank credit and more comfortable bank reserve positions, even though total reserves and money have expanded at a moderate rate. 